\title{
Water Quality of Canal For Sustainable Aquaculture in Reclaimed Tidal Lowlands
}

\author{
Raudhatus Sa'adah $^{1 *}$, M. Rasyid Ridho ${ }^{2,}$, Momon Sodik I ${ }^{2}$ \\ ${ }^{1}$ Magister Student of Environmental Management, Sriwijaya University, Indonesia \\ ${ }^{2}$ Lecturer in Magister Environmental Management, Sriwijaya University, Indonesia \\ *Corresponding Author: saadah_raudhatus@yahoo.com
}

Article history

\begin{tabular}{lllc}
\hline Received & Received from reviced & Accepted & Available online \\
09 September 2018 & 07 December 2018 & 19 December 2018 & 11 January 2019 \\
\hline
\end{tabular}

\begin{abstract}
The reclaimed tidal lowlands in Banyuasin District, South Sumatra, Indonesia was initiated by making channel that separate some area to be some land groups. Those water channel at the tidal location uses it for agriculture, plantations and also for the daily needs of the surrounding community. This research aimed to look at the feasibility of channel water quality in the Banyu Urip village for fisheries activities. The data analysis of water qualites data uses a cluster test to see a comparison of water quality from various types of channel that exist in tidal lowland areas. Water quality data analyzed were ammonia, phosphate, nitrate, TSS, DO, $\mathrm{pH}$, temperature, EC, salinity, depth canal water, detergent and organochlorine. Cluster tests are used to analyze data to compare water quality between canal areas. The water quality results obtained for detergent content have a range of 63.5-74.5 $\mu \mathrm{g} / \mathrm{l}$. Organochlorine content of pesticides obtained was eldrin content of $0.0084 \mathrm{ppm}$ while lindine, eldrin, heptchlor, DDT, endosulpan had values below $0.001 \mathrm{ppm}$. Cluster test showed that the water quality in the channel was still in good condition, and can be used to support fish culture.
\end{abstract}

Keywords: Reclaimed tidal lowlands, water canal, water quality, aquaculture

Abstrak (Indonesian): Reklamasi rawa pasang surut di Kabupaten Banyuasin, Sumatera Selatan, Indonesia diinisiasi dengan pembuatan kanal-kanal yang memisahkan wilayahnya menjadi beberapa kelompok. Kanal yang ada saat ini dilokasi pasang surut pemanfataannya untuk kegiatan pertanian, perkebunan dan juga untuk kebutuhan sehari-hari masyarakat sekitar. Penelitian ini bertujuan untuk melihat kelayakan kualitas air kanal yang ada di desa pasang surut Banyu Urip untuk kegiatan perikanan. Analisis data kualitas air menggunakan uji cluster untuk melihat perbandingan kualitas air dari berbagai jenis kanal yang ada di kawasan rawa pasang surut. Data kualiatas air yang dianalisis adalah amonia, fosfat, nitrat, TSS, DO, pH, suhu, EC, salinitas, kedalaman air kanal, detergen dan organoklorin. Uji Cluster digunakan untuk menganalisis data untuk membandingkan kualitas air di antara area kanal. Hasil kualitas air yang di dapat untuk kandungan detergen memiliki nilai kisaran 63,5-74,5. Kandungan Pestisida Organoklorin yang didapat adalah kandungan dieldrin sebesar 0,0084 ppm sedangkan kandungan lindin, eldrin, heptklor, DDT, endosulpan memiliki nilai di bawah 0,001 ppm. Uji Cluster menunjukkan bahwa kualitas air di saluran masih dalam kondisi baik, dan dapat digunakan untuk mendukung pemeliharaan ikan.

Kata kunci : Rawa pasang surut, kanal air, kualitas air, kegiatan perikanan.

\section{Introduction}

Tidal lowland has 20.14 million ha, spread over 17 provinces, of which around 9.53 million ha are declared to be used for agricultural activities in Indonesia. Currently, the swamp area that has been used is only around 5.27 million ha, of which 2.27 million ha is opened for the government transmigration program and 3.0 million ha is utilized by the community for self-supporting activities. The opening of tidal lowland was initiated with the construction of canals that connect the surrounding cities. The canals that were made also connect between the two rivers around the tidal land area so as to facilitate the flow of transport of ships (speedboat, getek and others) trade, and also science ${ }^{[8]}$.
Tidal lowland is a land whose water availability is affected by rainfall, sea tides and river runoff. Recently, tidal lowland reclamation are more widely used for agricultural and plantation activities [9]. Fisheries activities are still unpriority, whereas water quality and quantity in tidal low land is so potential and optimilizing its potential will make fisheries has great opportunity that should be developed and carried out in the reclamation area of tidal lowland ${ }^{[2]}$.

One of the transmigration village in Tanjung Lago Subdistrict, Banyuasin District, South Sumatra Province, is Banyu Urip village. The commodities that grown currently are rice in December-April and corn in May-September. Agricultural and plantation activities carried out by the community and pattern of water use 
by the community for household activities had given some effects as physically, chemically and biologically in water quality ${ }^{[7]}$.

The importance of preliminary studies of water quality both physical and chemical can be an indicator of the feasibility of water for fisheries activities. Water quality management that can be done earlier is to observe water quality parameters ${ }^{[6]}$. Research on water and environmental quality is necessary to do in the Banyu Urip village for recognizing the physical and chemical water quality regarding many activities carried out in Banyu Urip and finding out potential development of fish farming in each canal in Banyu Urip village.

\section{Material and Methods}

This research was conducted in Banyu Urip Village P17 6S, Tanjung Lago Subdistrict, Banyuasin District, South Sumatra Province during high tide condition in March-April 2018, considering about account the intensity of the rainfall. The retrieval method used was purposive sampling method at six (6) sampling points, namely Station 1 (Primary SDU), Station 2 (Primary SPD), Station 3 (Secondary/ SDU), Station 4 (Tertiary 11), Station 5 (Secondary/SPD) and station 6 (Tertiary 12). Water quality parameters were ammonia, phosphate, nitrate, TSS, DO, Temperature, $\mathrm{pH}$, EC, depth canal water, salinity, detergent and Organochlorine and also daily rainfall and tide fluctuation in March and April. Water quality result was analyzed with cluster test to identify the relation between each sampling station.

\section{Results and Discussion}

\subsection{Water Quality}

The water quality result in canals of Banyu Urip village in March and April 2018 and tide condition as follows :

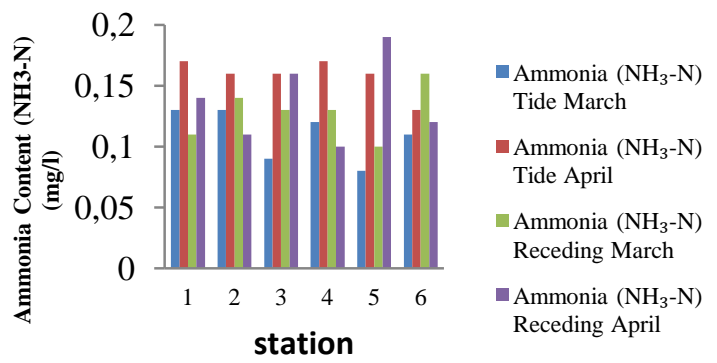

Figure 1. Ammonia Content

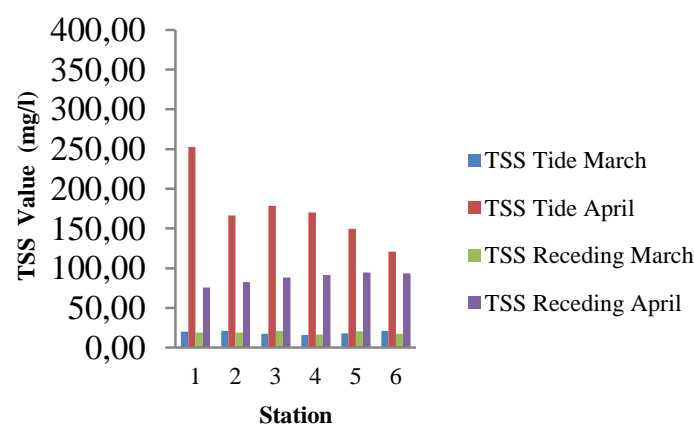

Figure 3. TSS

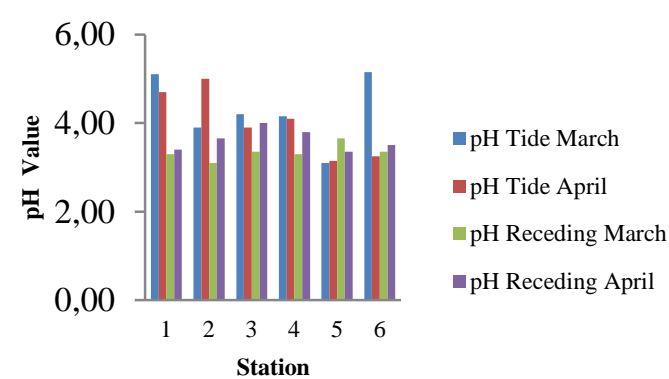

Figure 5.pH

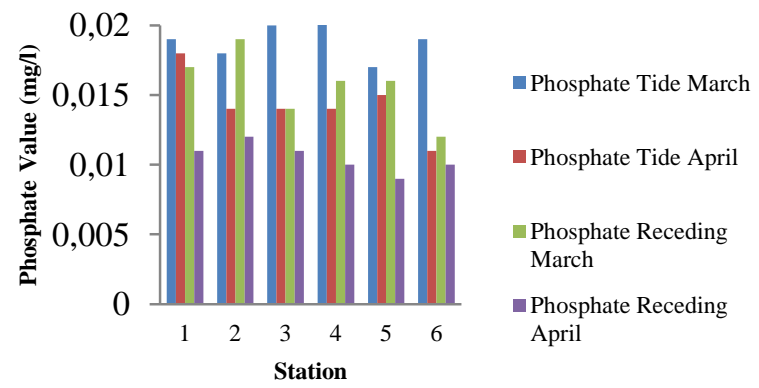

Figure 2. Phosphate Content

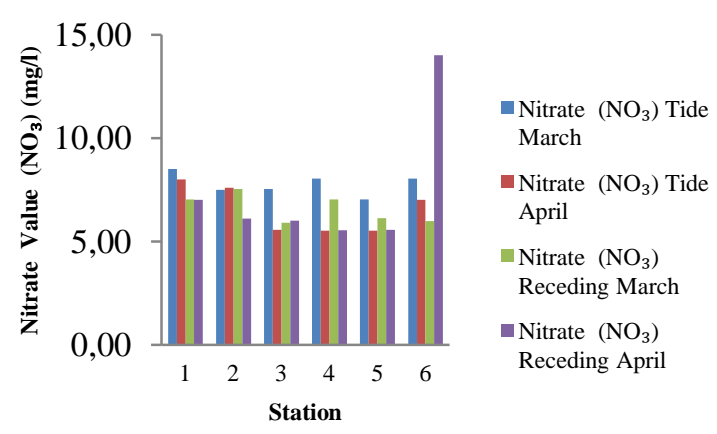

Figure 4. Nitrate

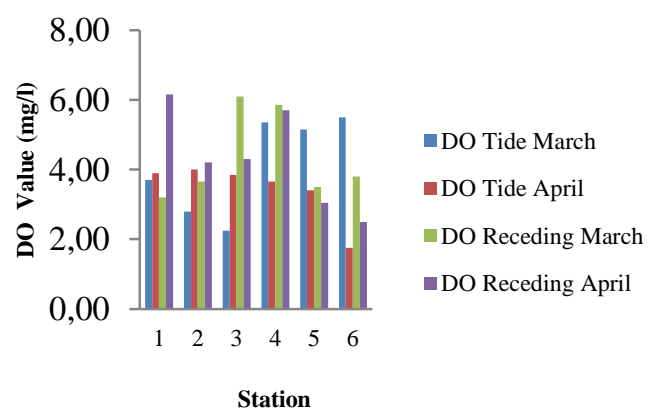

Figure 6. DO 


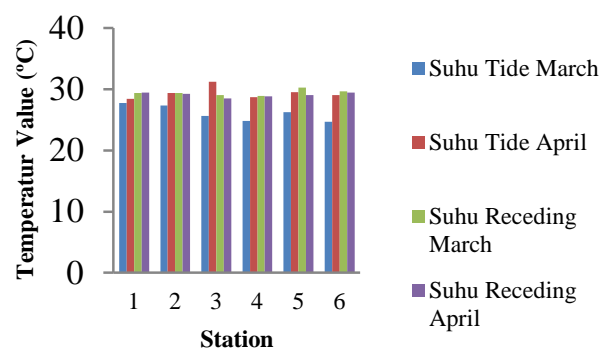

Figure 7. Temperature

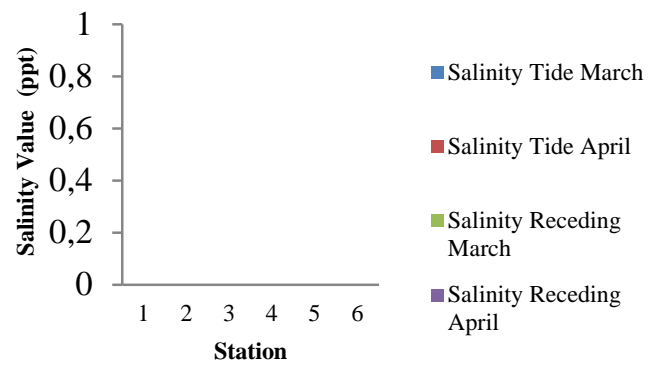

Figure 8. Salinity

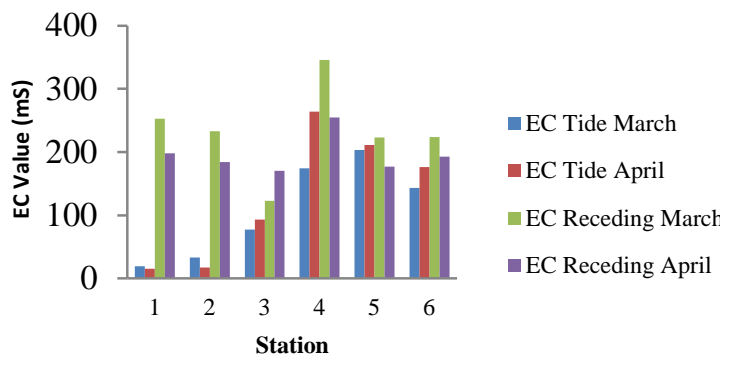

Figure 9. EC

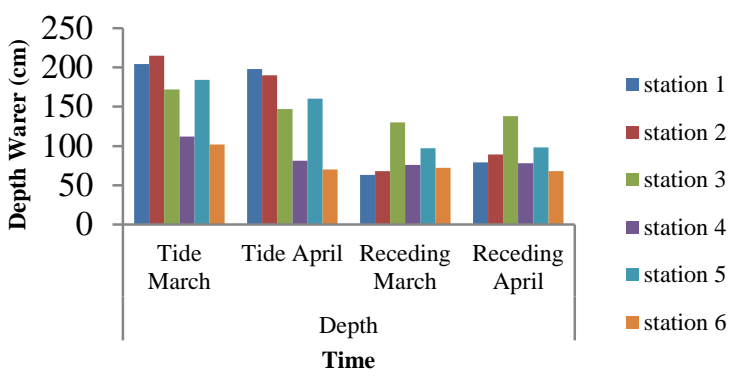

Figure 10. Depth canal water

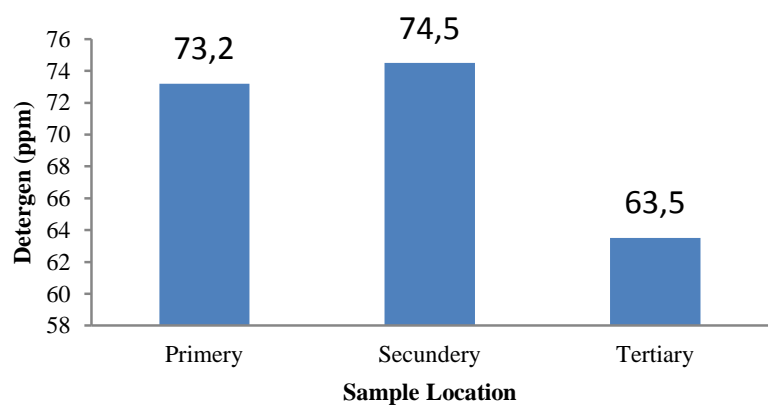

Figure 11. Detergent content

Ammount of ammonia $<0.002 \mathrm{mg} / \mathrm{l}$ during research was above of the standard quality ammonia for fisheries which is categorized in class III (Fig.1). Ammount of ammonia in March on high tide condition was between $0.08-0.13 \mathrm{mg} / \mathrm{l}$ and in low tide condition between 0.08-0.13 mg/l. Otherwise in April was 0.13$0.17 \mathrm{mg} / \mathrm{l}$ in high tide condition and $0.10-0.19 \mathrm{mg} / \mathrm{l}$ in low tide condition. According to ${ }^{[4]}$, great ammount of ammonia in tidal lowland at Muliasari village caused by daily activity of villagers arround the canals and agricultural activity near by sampling points. Free ammonia concentration greater than $0.2 \mathrm{mg} / \mathrm{l}$ could be toxic for some fishes and extreamly high ammonia level indicates from domestic activity, industry, and run off from agriculture activity. The greatest ammonia level in this research was in April high tide and low tide condition, it might be caused by low intensity of rainfall in April and made the ammonia level in water was increasing. Based on ${ }^{[6]}$ research said that low intensity of rainfall in dry season would affect bad condition of water quality.

Result of phosphat concentration during this research in high tide and low tide condition in March were 0.017-0.022 $\mathrm{mg} / \mathrm{l}$ and 0.012-0.019 $\mathrm{mg} / \mathrm{l}$, respectively. While, in April for high tide and low tide condition were 0.011-0.018 mg/l and 0.009-0.012 $\mathrm{mg} / \mathrm{l}$. Phosphat level in Banyu Urip waters still available for aquatic organisms, otherwise low concentration of phosphate make station has less fertil level. Phosphat concentration $<0.02$ categorized as low-fertility water and $>0.200$ categorized as greatfertility water. Ammount of TSS in March when tide and ebb condition were 15.75-21.20 mg/l and 16.65 $\mathrm{mg} / \mathrm{l}$ respectively. In April when high tide and low tide condition were 120.7-252.5 $\mathrm{mg} / \mathrm{l}$ and $75.60-84.8$ $\mathrm{mg} / \mathrm{l}$, respectively. 
A

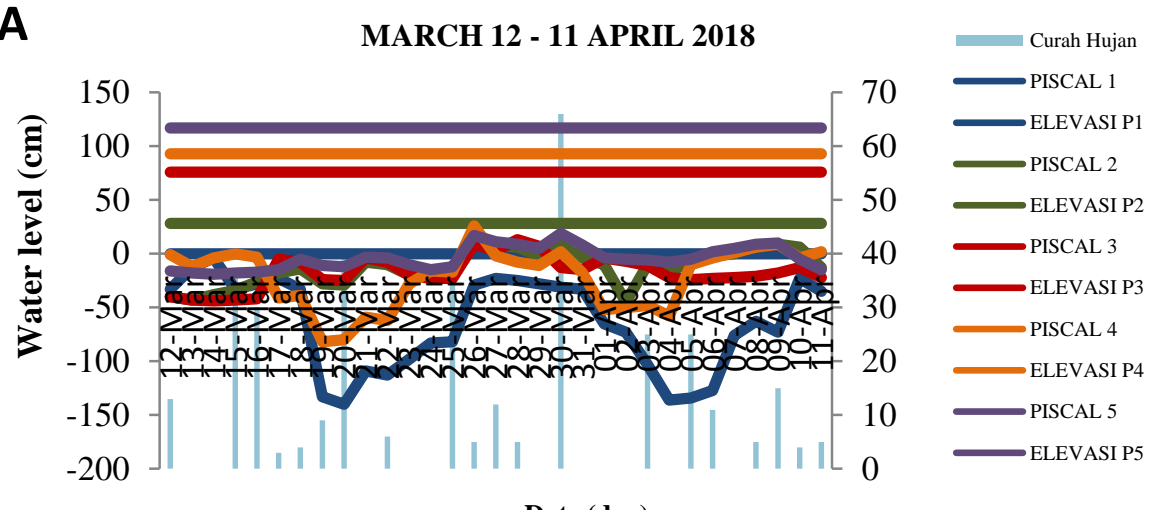

12 APRIL-12 MAY 2018

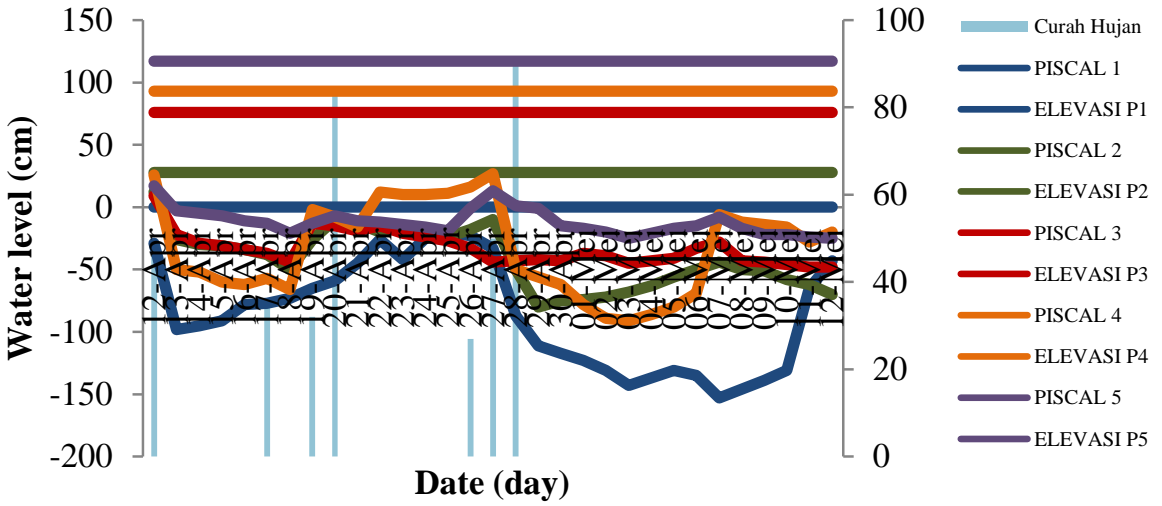

Figure 12. Water level in canal Banyu Urip Village (A dan B)

Table 1. Organochlorine Content Test Results

\begin{tabular}{lllll}
\hline Parameter & Method & Unit & $\begin{array}{l}\text { Sampel } \\
1(\mathrm{SPD})\end{array}$ & $\begin{array}{l}\text { Sampel 2 } \\
(\mathrm{TC})\end{array}$ \\
\hline Organoklorin & & & \\
Lindan & & $<0,001$ & $<0,001$ \\
Eldrin & Kormatografi & \multirow{2}{*}{ Ppm } & 0,0084 & $<0,001$ \\
Dieldrin & gas & & $<0,001$ & $<0,001$ \\
Heptklor & & & $<0,001$ \\
DDT & & & $<0,001$ & $<0,001$ \\
Endosulpan & & & $<0,001$ & $<0,001$ \\
\hline Source
\end{tabular}

Source : The Indonesian Center for Biodeversity and Biotechnology (ICBB), 2018

Graphic showed that Ammount of TSS in March even in high Tide or low tide condition were not slightly different. Otherwise, in April Ammount of TSS in high tide condition was greater than in low tide condition. TSS refers to the amount of matter suspended and dissolved in water, according to ${ }^{[4]}$ that ammount of TSS related to antrophoenic because high ammount of TSS would make turbidity. Based on research of ${ }^{[1]}$ conducted in Selat Madura Beach Bangkalan District, showed that water coloumn that mixed by suspended material has high turbidity value due to light penetration into water was block and give effect to photosynthesis process.

Nitrate concentration from all station were in the same condition, which been quite good enough in March and April in high Tide condition. Meanwhile in this research the highest nitrate consentration was in low tide condition in April at Station $614 \mathrm{mg} / \mathrm{l}$. It might caused by the position of that Station 6 is Tertiery canal which is quite near by field. ${ }^{[5]}$ said that high nitrate concentration was caused by run-off from agricultural waste and microorganism decomposition.

The $\mathrm{pH}$ value in high tide condition and low tide condition in March-April were 3.10-5.15 and 3.10$3.65 ; 3.15-5$ and 3.35-4.00, respectively. Based on value, condition of $\mathrm{pH}$ was acid, because in tidal lowland area tend to be acid due to various agricultural activity and also antrophogenic. The $\mathrm{pH}$ value in coastal areas generally lower than in the sea. That was because of the intrution water mass from river system [6].

DO level in high tide condition and low tide condition in March-April were 2.25-5.5 mg/l and 3.2$6.1 \mathrm{mg} / \mathrm{l} ; 1.75-4.00 \mathrm{mg} / \mathrm{l}$ and $2.5-6.15 \mathrm{mg} / \mathrm{l}$. DO level during this research was average greater than minimum for Fishery Standar value $3 \mathrm{mg} / \mathrm{l}$. It means that DO level in each stations was still available to support 
organisms growth. That was also mentioned by ${ }^{[3]}$ that DO Level for aquatic organisme is $3 \mathrm{mg} / \mathrm{l}$.

Temperature in high tide and low tide condition in March were $24.8-27.7^{\circ} \mathrm{C}$ and $28.9-30.25{ }^{0} \mathrm{C}$, respectively and in April were 28.4 to $31.2{ }^{\circ} \mathrm{C}$ and 28.4 $-29.4{ }^{0} \mathrm{C}$. Temperature in high tide and low tide condition were not slightly different, because high tide and low tide were in good condition for sampling at that time. However, in March at high tide condition, temperature was lower than others sampling time. It might caused by sampling time which taken in the morning with rainy conditions.

Salinity during the research in March and April and in the same condition of tide fluctuation were 0 ppt. This research was conducted during rainy season and it might causes the salinity values during the study was 0 ppt. Banyu Urip Village is categorize in Zone II, which is for this zone get fresh water tide effect, but in dry season, sea water tide will came into this area and cause salinity to be high. According to ${ }^{[6]}$ research in 2015, salinity value was 5-15 ppt for samples at long time dry season and the sampling location was overflow land B typed where influenced by tides entered from primary canal.

EC values obtained in March on tide conditions was 19-203 $\mathrm{mS}$ and ebb condition was 15-264 mS. Otherwise in April high tide conditions range was 123$346 \mathrm{mS}$ and the low tide condition was 170-198 $\mathrm{mS}$. EC conductivity value showed that there was turbidity in those waters. During the research, the conductivity values at low tide conditions were greater than the high tide conditions. This condition might because in low tide canals water became turbid and causes the turbidity value. The influence of water table at sampling was assumed be able to affect the value of EC conductivity.

Canal water depths measurement carried out in March and April at high and low tide conditions at the same time sampling. Depth in each station was different. The depth differences among station 1, 2 and 5 can be seen clearly betwen high tide and low tide condition, meanwhile depth at stations 3, 4, and 6 in high tide and low tide condition were not slightly different. It might be due to water flow condition in canal, stations 1,2, and 5 are primary channel (SDU), primary (SPD), and SPD canal were not overgrown with vegetation so that water can be flow smoother when incoming and outgoing water condition. However, at stations 3, 4 and 6 are SDU, tertiary 11 and tertiary 12 where the condition of the canal was a lot of plant vegetation due tothe flow of incoming and outgoing water was not smooth and depth value obtained was not slightly different.

The results of detergent content in the primary, secondary, and tertiary canal were $73.2 ; 74.5 \mathrm{ppm}$ and $63.5 \mathrm{ppm}$, respectively. The greatest detergent content was in the secondary canal (SPD) where the channel is widely used by villagers for daily activities such as washing and bathing. The detergent content obtained during the research in Banyu Urip village did not exceed the quality standard threshold according to the South Sumatra Governor's regulation in 2005 (200 ppm) so detergent content in Banyu Urip village was still in undengerous condition.

Sampling was conducted on March 25 and April 11, 2018 and high tide, low tide and rainfall rate can be seen on the graphic. Tide sampling points were in 5 stations namely station 1 (primary SDU), station 3 (SDU), station 4 (tertiary 11), station 5 (SPD) and station 6 (tertiary 12). The piscal board set in each channels. The difference of elevation makes a differences in height on each observation station. Rainfall also became influencer for water canal condition. Those high and low tide condition are water resource for villagers daily activity. Fisheries activities require appropriate water conditions for fish. According to ${ }^{[6]}$ that canal water in the village of Muliasari can be used as water source for fish pond to fish rearing fish in high tide condition and rainy season. Because if there is no high rainfall, water quality will not become suitable for fisheries.

The results of pesticide testing of organochlorine content showed values that did not exceed the threshold. It can be seen in the table that almost all of the organochlorine content, namely lindin, eldrin, heptchlor, DDT and endosulpan was $<0.001 \mathrm{ppm}$, this indicates that the value of the compound was low rate. The content of dieldrin in sample 1 (SPD) was 0.008 ppm while in sample 2 (tertiary) was $<0.001 \mathrm{ppm}$ which showed a difference in the values of both samples but the value had not exceeded the dieldrin content threshold in the waters. Agricultural activity used pesticides every planting season, so that their use will continue to increase, the effect is not only on the crop but also on the water which affects living aquatic organisms. It needs attention to dosage of its use so that the water conditions can still be used for the life of aquatic organisms like fish and plankton. Organochlorine has a level of toxicity that has the characteristics of tissue damage or death in both insects and humans. According to ${ }^{[11]}$ organochlorine toxicity is divided in: very toxic, namely aldrin, endosulfan and dieldrin. Simple toxicants are clordane, DDT, lindane and heptachlor. Less toxic is benzanehexacloride (BHC).

\subsection{The relationship between water quality and various types of canals}

In the picture of the dendogram showed the similarity of water quality characteristics both chemistry and physics. In Figure. 14, sampling in March has 3 groups formed and explained that the group had similar water quality characteristics among stations. The first group consisted of SS4, Group two 
consisted of PS4, SS3, PS3, SS1, SS2, SS6, and SS3, and the third group consisted of PS6, PS3, PS2, and PS1. In Figure. 15 in April sample also formed 3 three groups consisting of the first group namely PS4 and PS5, group two consisted of PS6, SS1, SS6, SS2, SS5, and SS4, group three consisted of PS3, SS3, PS2 and PS1.In March the first group consisted only of station 4 in low tide, station 4 is a tertiary canal that had water quality values that were different from other stations. The different water quality values at station 4 is the highest EC values at low tide was $346 \mathrm{mS}$.

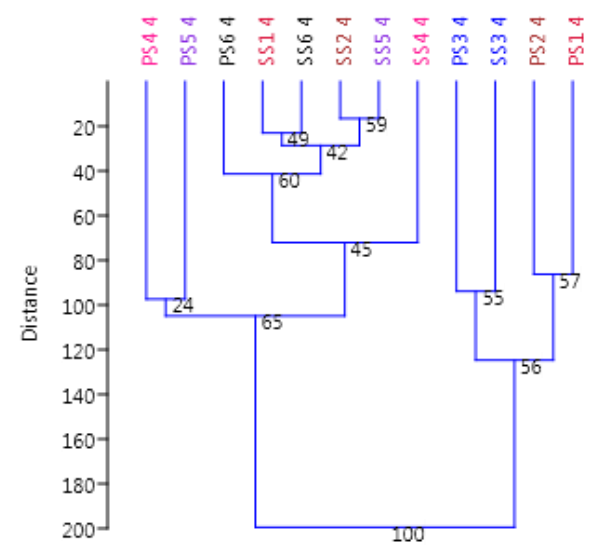

Fig 14. Water quality Dendogram (25 Maret 2018)

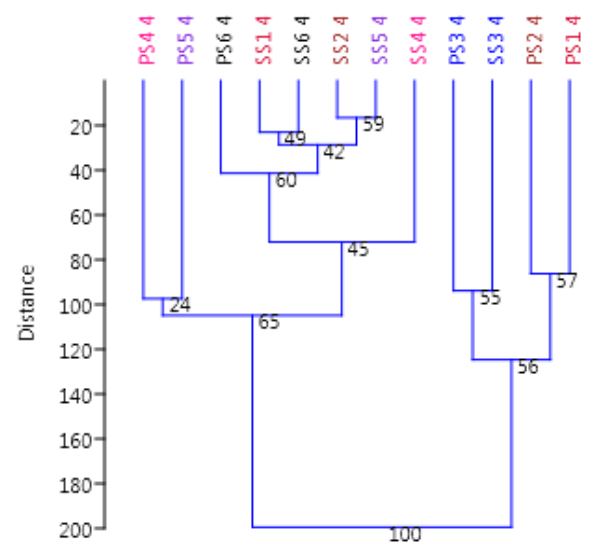

Fig 14. Water quality Dendogram (11 April 2018)

Information : $\mathrm{P}=$ Install $\mathrm{S}=$ receding

The second group, almost all stations in low tide conditions at stations $1,2,3,5$ and 6 have same character values but there are 2 stations in high tide conditions that have the same value character with low tide conditions at station 4 and station 3. Station 3 in High Tide and low tide condition station has the same character of water quality value because the condition of many canals was overgrown with plants in the canal so the water can not coming in and out going smoothly and causes good water quality even in high tide and low tide conditions.
The third group consisted of the high tide conditions of station 6, station 3, station 2 and station 1. Station 6 and station 3 were secondary canals and related tertiary canals so that the quality of water in the canal were almost the same. Station 2 and station 1 were the primary locations in SDU and SPD and the canal condition was so clean from plant vegetation and environmental conditions were almost the same, and also as a location of the dismissal of ships carrying coconut so the water quality conditions both high tide and low tide were almost same.

In April the first group consisted of tide conditions station 4 and station 5 . This might be tertiary and secondary canals has same relation like third group in March. Group 2 also dominated by low tide condition which almost same like in March and consist of station 1, 2, 4, 5 and 6 and one tide condition at station 6. Whereas in the third group consisted of high tide conditions in station 1, 2 and 3 and low tide condition in station 3 . In the condition of high tide and low tide station 3 in April has the same character as March with the same channel conditions. And also the high tide condition at station 1 and station 2 with the same station location in March.

The condition of the canal that connected between tertiary canals, secondary canals and primary canals was one of the causes of water quality characters that were almost the same and have relation to each other. The results of cluster analysis in March and April made 3 groups consisting of almost the same stations as the station 3 characters, both the same tidal conditions in April and March. As well as tidal conditions at station 1 and station 2 also have the same character in March and April. In the research of ${ }^{[5]}$ stated the character of water quality of high tide and low tide condition in the village of Muliasari had values that were not much different so that the water conditions both high tide and low tidequite same.

Water conditions in secondary, tertiary and primary canals have potential for aquaculture activities. The same water quality among each stations showed that water quality can still be used for fishery activities. The high tide conditions have better character values than the low tide conditions and more suitable of cultivation activities. Fish cultivation activities can be carried out in canals directly or canal water used to ponds media. As a result of the research by ${ }^{[6]}$ that the condition of Muliasari village canal water was better in high tide conditions and when rainfall is high. So that the water enters the pond by utilizing high tide conditions.

\section{Conclusion}

The conclusions in this study are:

1. Ammonia water quality and the $\mathrm{pH}$ has exceeded the environmental quality standard threshold so 
need special attention to be able to regulate the use of organic materials in pady field.

2. The cluster test showed that almost same values in March and April from the formation of 3 groups in which the group consists of codition among station 3 , station 1 and station 2 was good high tide and low tide condition.

3. The water quality of the high tide conditions has better value than low tide conditions.

4. Aquaculture activities can be carried out in the canal directly or in ponds using high tide conditions and high rainfall.

\section{Acknowledgement}

Water quality data collection that is more supportive for fisheries activities plans should be taken during the rainy season in November-April so that changes in water quality during the rainy season can be seen to support fisheris aquaculture.

\section{References}

[1] I.W. Adiba. "Produktivitas primer fitoplankton dan keterkaitannya dengan intensitas cahaya dan ketersediaan nutrien pada perairan selatan madura Kabupaten Bangkalan". Prosiding SENTA, Institut Teknologi Surabaya, 2008, pp.

[2] M. Fitrani. "Potensi penggunaan lahan pekarangan masyarakat transmigrasi daerah pasang-surut untuk budidaya perikanan". Prosiding Seminar Nasional, Masyarakat Konservasi Tanah dan Air Indonesia. Palembang, 2013, pp. 229-234.

[3] C.R. Goldman and A.J. Horne. Limnology. Mac Graw Hill, New York, 1983, pp.

[4] I. Hamida. Kajian kualitas berbagai sumber air daerah pasang surut pada musim kemarau di Desa Muliasari Kecamatan Tanjung Lago. Tesis. Program Studi Pengelolaan Lingkungan. PPS, Universitas Sriwijaya, 2017, pp.
[5] E.N. Khairunnisa., Z. Hanafiah dan D. Putro. "Komposisi dan kelimpahan fitoplankton di perairan saluran irigasi pasang surut di Desa Mulia Sari Kecamatan Tanjung Lago". "Maspari Journal", vol 9, pp. 159-168. 2017.

[6] Marsi., R.H. Susanto dan M. Fitrani. "Karakteristik fisik dan kimia sumber air canal di lahan rawa pasang surut untuk budidaya perikanan". "Jurnal Perikanan dan Kelautan”, vol 21, pp. 17-25. 2016.

[7] Y.V. Munthe., R. Aryawati dan Isnaini. "Struktur komunitas dan sebaran fitoplankton di perairan sungsang Sumatera Selatan". "Maspari Journal", vol 4, pp. 122-130. 2012.

[8] M. Noor dan A. Rahman. "Biodiversitas dan kearifan lokal dalam budidaya tanaman pangan mendukung kedaulatan pangan : kasus lahan rawa pasang surut". Prosiding Seminar Nasional Masyarakat Biodeversitas Indonesia, vol 1, pp. 1861-1867. 2015.

[9] Susanto, R. H. "Potensi dan strategi pemanfaatan lahan basah untuk pertanian, peternakan dan perikanan". Prosiding seminar nasional lahan subobtimal, Intensifikasi pengelolaaan lahan suboptimal dalam rangka mendukung kemandirian pangan nasional", 2013, pp.

[10] S.T.H. Wardoyo. "Kriteria kualitas air untuk keperluan pertanian dan perikanan". Training Analisa Dampak Lingkungan . PPLH-UNDPPUSDI_PSL. IPB. Bogor. 1982.

[11] MG.C. Yuantari. " Dampak pestisida organoklorin terhadap kesehatan manusia dan lingkungan serta penanggulangan". Prosiding Seminar Nasional Peran Kesehatan Masyarakat dalam Pencapaian MDG's di Indonesia, 2011, pp. 187 199. 